Fothergill, P. G. \& Jones, M. (1958). J. gen. Microbiol. 19, 298-304

\title{
Nutritional Studies of Zygorhynchus Species
}

\author{
By P. G. FOTHERGILL \\ Botany Department, King's College, Newcastle upon Tyne \\ AND MARGARET JONES \\ Guinness and Son's Laboratory, Park Royal Brewery, \\ London, N.W. 10
}

\begin{abstract}
SUMMARY: Nutritional experiments were carried out dealing with: (1) the utilization of carbohydrates; (2) the nitrogen source; (3) the action of different mineral salts and their interaction. The results showed that the strains of Zygorhynchus used grew well at $25^{\circ}$ at $\mathrm{pH} \mathrm{8.0}$ when buffered with nutritionally inert tris buffer and incubated for 12-14 days. Statistical analysis of the results showed that under the given conditions optimal growth measured as mg. dry wt. was obtained in liquid media containing $4 \%(\mathrm{w} / \mathrm{v})$ glucose; $0.1 \mathrm{M}$ tris buffer; $0.00625 \mathrm{M}-\left(\mathrm{NH}_{4}\right)_{2} \mathrm{SO}_{4} ; 2$ p.p.m. $\mathrm{Fe}, \mathrm{Zn}$ and $\mathrm{Mn}$; with the following optimal conditions for the different strains specified: (i) for $\mathrm{Z}$. moelleri CMI $0.002 \mathrm{M}-\mathrm{KH}_{2} \mathrm{PO}_{4} ; 0.012 \mathrm{M}-\mathrm{MgSO}_{4} .7 \mathrm{H}_{2} \mathrm{O}$; (ii) for Z. moelleri Baarn 0.002 $\mathrm{M}-\mathrm{KH}_{2} \mathrm{PO}_{4} ; 0.006 \mathrm{M}-\mathrm{MgSO}_{4} .7 \mathrm{H}_{2} \mathrm{O}$; (iii) for $\mathrm{Z}$. vuillemini CMI 0.002 M- $\mathrm{KH}_{2} \mathrm{PO}_{4} ; 0.003 \mathrm{M}-\mathrm{MgSO}_{4} .7 \mathrm{H}_{2} \mathrm{O}$; (iv) for Z. vuillemini Baarn 0.004 M$\mathrm{MgSO}_{4} .7 \mathrm{H}_{2} \mathrm{O}$. There was a balance between the possible pairs of the salts from $\mathrm{KH}_{2} \mathrm{PO}_{4}, \mathrm{MgSO}_{4} \cdot 7 \mathrm{H}_{2} \mathrm{O}$ and $\left(\mathrm{NH}_{4}\right)_{2} \mathrm{SO}_{4}$ (in one case only between $\mathrm{KH}_{2} \mathrm{PO}_{4}$ and $\mathrm{MgSO}_{4} .7 \mathrm{H}_{2} \mathrm{O}$ ). There was an optimal balance between all the salts for two strains. The best carbon sources were glucose, fructose, mannose, xylose and arabinose. The best sources of nitrogen were L-glutamine, L-asparagine, glycine, $\left(\mathrm{NH}_{4}\right)_{2} \mathrm{SO}_{4}$.
\end{abstract}

In 1953 Burges \& Fenton observed that in the acid soils of East Anglia Zygorhynchus vuillemini was abundant below $10 \mathrm{~cm}$., but relatively scarce in the surface regions; this distribution was correlated with a high tolerance to carbon dioxide. Several workers have studied the effect of different media on the reproductive processes of Zygorhynchus spp. but no detailed account of the general mineral nutrition of members of this genus has been given. The purpose of the present paper is to report on a nutritional study of some different Zygorhynchus spp.

\section{METHODS}

The following organisms were used. Zyorhynchus moelleri and Z. vuillemini from the Commonwealth Mycological Institute (CMI) which are zygosporeproducing strains; $\boldsymbol{Z}$. moelleri and $\boldsymbol{Z}$. vuillemini from the Central Bureau voor Schimmelculture, Baarn (Baarn), which were non-zygospore-producing strains. Throughout this paper the following abbreviations are used: CMI strains are designated $\mathrm{MC}$ and $\mathrm{VC}$, respectively, while the Baarn strains are designated MB and VB, respectively.

Single spore cultures of these fungi were kept as stocks in 6 in. $\times \frac{3}{4}$ in. test tubes on potato glucose agar at $0^{\circ}$ and subcultured as required. No alteration of morphological and cultural characteristics of these fungi occurred during the 
period of the experiments. Exploratory experiments with VC showed that in phosphate-containing media a good source of inorganic nitrogen was $\left(\mathrm{NH}_{4}\right)_{2} \mathrm{SO}_{4}$, but the use of this substance led to an accumulation of $\mathrm{H}_{2} \mathrm{SO}_{4}$ in the medium (see also Machlis, 1953; Fothergill \& Yeoman, 1956), to a consequent decline in $\mathrm{pH}$ value, and to the phosphate acting as a buffer as well as a nutrient. The use of an inert buffering agent was thus desirable. Tris buffer (2-amino-2-hydroxymethylpropane-1:3-diol) was found to be suitable.

In the nutritional experiments inoculations were made into a final volume of $25 \mathrm{ml}$. sterile culture fluid in Pyrex Erlenmeyer flasks (150 ml.) and incubated at $25^{\circ}$. Sterile phosphate solution was added aseptically from a glass syringe after autoclaving in order to avoid precipitation. The inoculum was a suspension of spores and mycelial fragments made by adding $10 \mathrm{ml}$. sterile distilled water to a suitable agar slope, shaking and decanting the liquid; $1 \mathrm{ml}$. of which was then added to each culture flask of liquid medium. It was found that the exact amount of the inoculum did not appreciably affect the amount of growth within the limits of the experiments.

All experiments were carried out on five replicates unless otherwise stated. After the growth period the mycelia were filtered on to tared Whatman No. 5 filter-papers and washed with distilled water. The mycelium with the filterpapers was then dried overnight at $85^{\circ}$, cooled in a desiccator and weighed; results are expressed as $\mathrm{mg}$. dry wt. mycelium/flask. It was not found practical to separate mycelium from filter-paper after filtration, and as these filter-papers lose $7 \%$ of their original weight on drying under the above conditions, appropriate allowance was made for this. For preliminary experiments the following basal defined liquid medium $A$ was used: $4 \%(w / v)$ glucose; $0.004 \mathrm{M}-\mathrm{KH}_{2} \mathrm{PO}_{4} ; 0.002 \mathrm{M}-\mathrm{MgSO}_{4} .7 \mathrm{H}_{2} \mathrm{O} ; 0.0125 \mathrm{M}-\left(\mathrm{NH}_{4}\right)_{2} \mathrm{SO}_{4} ; \mathrm{Zn}, \mathrm{Fe}$ and $\mathrm{Mn}$ at 2 p.p.m.

When tris buffer to $0 \cdot 1 \mathrm{M}$ was used the mineral constituents had be modified for maximum growth in all cases to contain 0.002 $\mathrm{M}-\mathrm{KH}_{2} \mathrm{PO}_{4} ; 0.006 \mathrm{M}-\mathrm{MgSO}_{4}$. $7 \mathrm{H}_{2} \mathrm{O}$; and $0.00625 \mathrm{M}-\left(\mathrm{NH}_{4}\right)_{2} \mathrm{SO}_{4}$; the complete modified medium containing tris buffer will be referred to as medium B. Preliminary experiments indicated that the temperature for maximum mycelial yield was $25^{\circ}$; a decrease in dry weight began on the 12th day of incubation with organisms $\mathrm{MC}$ and $\mathrm{VC}$, and on the 14th day for organisms MB and VB.

\section{RESULTS}

\section{Carbon requirements}

The utilization of different carbon compounds by the strains of Zygorhynchus used was determined after 7-, 14- and 28-day growing periods. The basal medium B was used, but glucose was replaced by other carbon compounds at $15 \mathrm{~g}$./l. Caramelization of the sugars was largely avoided by careful autoclaving, although this usually occurred to a small degree. The $\mathrm{pH}$ value of the resultant solutions after the addition of carbohydrates was adjusted to 8.0 which is a favourable value for these fungi. The following carbohydrates were used in this experiment, glucose, fructose, mannose, galactose, sorbose, 
arabinose, xylose, maltose, lactose, sucrose and raffinose. The results showed that there was a large variation among the organisms tested in their ability to use, and their rate of utilization of, the different carbohydrates. After 7 days of incubation of organism MC only glucose, fructose and mannose were utilized to any large extent, but after 28 days yields of about $170 \mathrm{mg}$. dry wt. mycelium were obtained, and also with galactose or mannose; yields of mycelium with xylose and arabinose were also high. A similar pattern of utilization obtained also for organism MB but with a smaller yield of mycelium. With sucrose organism MB produced $141 \mathrm{mg}$. dry wt. after 28 days as against $24 \mathrm{mg}$. for organism MC. Incubation of organisms MC and MB for 7 days gave relatively small yields with all carbohydrates, but after 14 and 28 days all except sorbose, lactose and raffinose were utilized. The Baarn strains, unlike the CMI strains, utilized sucrose (125 mg. dry wt. mycelium as against $36 \mathrm{mg}$.). Maltose gave only $41 \mathrm{mg}$. dry wt. of mycelium with organism MB after 14 days but $132 \mathrm{mg}$. after 28 days incubation; organism MC gave $161 \mathrm{mg}$. dry wt. mycelium with arabinose, while organism MB gave only $35 \mathrm{mg}$. In general, both of the CMI strains gave consistently higher weights of mycelium than the Baarn strains.

Lilly \& Barnett (1953) made a comprehensive study of the effect of sugars on the growth of a large number of fungi which included Zygorhynchus vuillemini. Their basal medium, however, differed from that used here and the $\mathrm{pH}$ value was considerably lower. A comparison is therefore not strictly accurate, but nevertheless may be made. In both sets of experiments glucose, fructose, mannose and galactose were good sources of carbon, while sorbose and lactose were the poorest sources. Organism VC was again exceptional as giving a high yield with arabinose.

\section{Nitrogen requirements}

In this experiment the effect of different sources of nitrogen was determined. The basal medium $B$ was used with glucose and the nitrogen salt was varied but supplied at a nitrogen concentration equivalent to $0.00625 \mathrm{M}$ $\left(\mathrm{NH}_{4}\right)_{2} \mathrm{SO}_{4}$. The $\mathrm{pH}$ value was adjusted to $8 \cdot 0$ in all cases. With all strains used there was a steady increase in nitrogen utilization in all its forms tested during 7-14 days of incubation; at 28 days there was less dry wt. of mycelium than at 14 days. In all strains the highest yields of mycelium were obtained with L-glutamic acid, L-asparagine or glycine (from 182 to $236 \mathrm{mg}$. dry wt. mycelium); $\left(\mathrm{NH}_{4}\right)_{2} \mathrm{SO}_{4}$, and $\mathrm{NH}_{4} \mathrm{NO}_{3}$ gave the next highest average yields (156-163 mg. dry wt. mycelium); while aspartic acid gave $121 \mathrm{mg}$. and $\mathrm{KNO}_{3}$ only $76 \mathrm{mg}$. In general, as with the carbon requirement, the Baarn strains gave consistently lower yields of mycelium than those from the CMI. Thus these fungi fall into Robbins's (1937) second class according to their ability to utilize mineral nitrates, ammonium salts and organic forms of nitrogen.

\section{Factorial experiments}

The object of these experiments was to determine the effect of varying the concentration of the mineral salts and ammonium sulphate in the basal 
medium. The factorial design and statistical analysis of the results should indicate whether or not a balance between the salts is necessary for high mycelial yields under the given conditions. The direct effect of the individual salts in the medium and the interaction between them is also determined. Medium B was used in these experiments; cultures were incubated at $25^{\circ}$ for 12 days for CMI strains and for 14 days for Baarn strains. The results were expressed as mg. dry wt. mycelium average of four replicates in each case. The concentrations of the salts were fixed on the basis of halving and doubling them in the basal medium. Thus, $\mathrm{KH}_{2} \mathrm{PO}_{4}, \mathrm{MgSO}_{4} .7 \mathrm{H}_{2} \mathrm{O}$ and $\left(\mathrm{NH}_{4}\right)_{2} \mathrm{SO}_{4}$ were each used at three concentrations and all possible combinations of them were set up. In any one experiment with any one strain 108 culture flasks were incubated. The initial $\mathrm{pH}$ value of all solutions was 7.8-8.0 and any tendency for a decrease in $\mathrm{pH}$ value was controlled by the tris buffer. The results are shown in Tables 1 and 2 and the analyses of variance in Table 3.

Table 1. Growth responses of four strains of Zygorhynchus moelleri and Z. vuillemini to varying concentrations of $\mathrm{KH}_{2} \mathrm{PO}_{4}, \mathrm{MgSO}_{4} \cdot 7 \mathrm{H}_{2} \mathrm{O}$ and $\left(\mathrm{NH}_{4}\right)_{2} \mathrm{SO}_{4}$

Concentration of $\mathrm{KH}_{2} \mathrm{PO}_{4}: \mathrm{P}_{1}, \mathrm{P}_{2}, \mathrm{P}_{3}=0.001 \mathrm{M}, 0.002 \mathrm{M}, 0.004 \mathrm{M}$; of $\mathrm{MgSO}_{4} .7 \mathrm{H}_{2} \mathrm{O}: \mathrm{Mg}_{1}, \mathrm{Mg}_{2}, \mathrm{Mg}_{3}=$ $0.008 \mathrm{M}, 0.006 \mathrm{M}, 0.012 \mathrm{M}$; of $\left(\mathrm{NH}_{4}\right)_{2} \mathrm{SO}_{4}: \mathrm{N}_{1}, \mathrm{~N}_{2}, \mathrm{~N}_{3}=0.003125 \mathrm{M}, 0.00625 \mathrm{M}, 0.0124 \mathrm{M}$.

A. Z. moelleri CMI (=MC) and Z. moelleri Baarn (=MB)

\begin{tabular}{|c|c|c|c|c|c|c|c|c|c|c|c|c|c|c|c|c|c|}
\hline \multicolumn{6}{|c|}{$\mathbf{P}_{1}$} & \multicolumn{6}{|c|}{$\underbrace{\mathbf{P}_{2}}$} & \multicolumn{6}{|c|}{$\mathbf{P}_{8}$} \\
\hline \multicolumn{2}{|c|}{$\mathbf{M g}_{1}$} & \multicolumn{2}{|c|}{$\mathrm{Mg}_{2}$} & \multicolumn{2}{|c|}{$\mathrm{Mg}_{3}$} & \multicolumn{2}{|c|}{$\mathrm{Mg}_{1}$} & \multicolumn{2}{|c|}{$\mathbf{M g}_{2}$} & \multicolumn{2}{|c|}{$\mathbf{M g}_{3}$} & \multicolumn{2}{|c|}{$\mathbf{M g}_{1}$} & \multicolumn{2}{|c|}{$\mathbf{M g}_{2}$} & \multicolumn{2}{|c|}{$\mathbf{M g}_{3}$} \\
\hline MC & MB & $\mathrm{MC}$ & MB & MC & $\begin{array}{c}\mathrm{MB} \\
\mathrm{Me}\end{array}$ & $\begin{array}{l}\mathbf{M C} \\
\text { an } \mathbf{d r}\end{array}$ & MB & $\begin{array}{c}\text { MC } \\
\text { myce }\end{array}$ & MB & $\begin{array}{c}\text { MC } \\
\mathrm{mg} \cdot / \mathrm{f}\end{array}$ & $\begin{array}{l}\text { MB } \\
\text { lask) }\end{array}$ & MC & MB & MC & MB & MC & $\mathbf{M B}$ \\
\hline 123 & 117 & 125 & 123 & 132 & 120 & 134 & 118 & 135 & 118 & 136 & 117 & 130 & 116 & 131 & 119 & 148 & 127 \\
\hline 164 & 152 & 169 & 155 & 176 & 158 & 175 & 168 & 178 & 170 & 183 & 162 & 143 & 171 & 166 & 165 & 182 & 166 \\
\hline 147 & 154 & 160 & 155 & 165 & 155 & 140 & 148 & 144 & 145 & 161 & 144 & 125 & 147 & 127 & 14,2 & 184 & 142 \\
\hline
\end{tabular}

B. Z. vuillemini CMI (=VC) and Z. vuillemini Baarn (=VB)

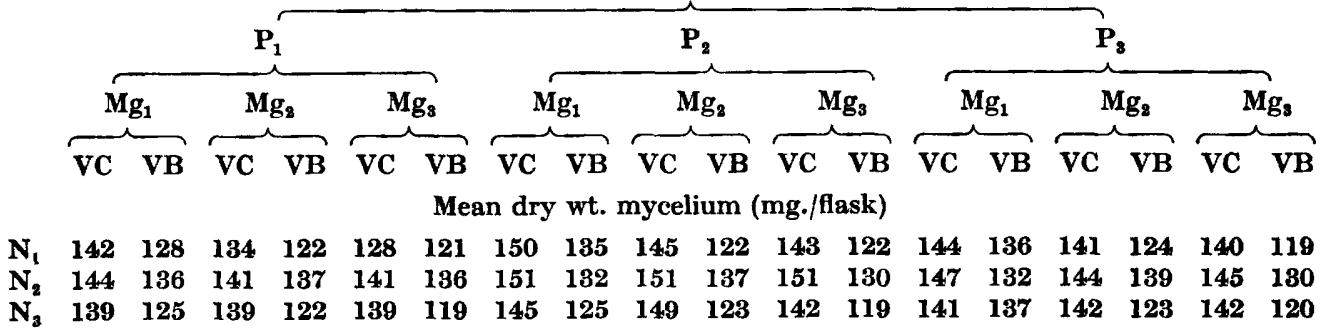

With organism MC there were significant differences between the yields and all concentrations of salts used except between $0.001 \mathrm{M}$ and $0.002 \mathrm{M}-\mathrm{KH}_{2} \mathrm{PO}_{4}$. The highest yield was produced with $\mathrm{P}_{2}, \mathrm{Mg}_{3}$ and $\mathrm{N}_{2}$, which gave $183 \mathrm{mg}$. dry wt. mycelium. With organism MB there was no significant difference in yields with any of the concentrations of either $\mathrm{KH}_{2} \mathrm{PO}_{4}$ or $\mathrm{MgSO}_{4}$. Ammonium sulphate at $0.00625 \mathrm{M}$ gave $163 \mathrm{mg}$. dry wt. mycelium. The best growth was obtained with combination $\mathrm{P}_{2}, \mathrm{Mg}_{2}$ and $\mathrm{N}_{2}$. With organism $\mathrm{VC}$, except for the $0.002 \mathrm{M}$ concentration where the increase of dry wt. was $10 \mathrm{mg}$., any 
increases in dry weights were small but significant. The highest weight of mycelium produced was with $\mathrm{P}_{2}, \mathrm{Mg}_{1}$ and $\mathrm{N}_{2}$. With organism $\mathrm{VB}$ all concentrations of $\mathrm{MgSO}_{4}$ and $\left(\mathrm{NH}_{4}\right)_{2} \mathrm{SO}_{4}$ produced significant differences of yield, but with $\mathrm{KH}_{2} \mathrm{PO}_{4}$ the variation in yield was not large. The highest yield of mycelium with organism VB was produced with $\mathrm{P}_{3}, \mathrm{Mg}_{1}$ and $\mathrm{N}_{2}$. With all strains $0.00625 \mathrm{M}-\left(\mathrm{NH}_{4}\right)_{2} \mathrm{SO}_{4}$ gave the highest yields. The analyses of variance show that all first-order interactions were significant except that between $\mathrm{KH}_{2} \mathrm{PO}_{4}$ and $\mathrm{MgSO}_{4}$; with organism VC that between $\left(\mathrm{NH}_{4}\right)_{2} \mathrm{SO}_{4}$ and $\mathrm{MgSO}_{4}$ was significant only at the lower 19:1 odds. It is evident that with all four strains of Zygorhynchus used the concentration of ammonium sulphate and the interaction of this with $\mathrm{KH}_{2} \mathrm{PO}_{4}$ were important in order to obtain high yields of mycelium. In the second-order interactions between the three salts taken together only organism MC showed a high interaction at the 99:1 level of significance and organism MB at the 19:1 level.

Table 2. Mean dry weights and growth responses of Zygorhynchus spp. after 12 and 14 days incubation at $25^{\circ}$ on media with different concentrations of certain components

Concentrations of salts as in Table $1, \mathrm{KH}_{2} \mathrm{PO}_{4}=\mathrm{P}_{1}, \mathrm{P}_{2}, \mathrm{P}_{3} ; \mathrm{MgSO}_{4} .7 \mathrm{H}_{2} \mathrm{O}=\mathrm{Mg}_{1}, \mathrm{Mg}_{2}, \mathrm{Mg}_{3}$; $\left(\mathrm{NH}_{4}\right)_{2} \mathrm{SO}_{4}=\mathrm{N}_{1}, \mathrm{~N}_{2}, \mathrm{~N}_{3}$. Difference required between weights for odds of $99: 1$ for strain $M C=2 \cdot 78$; for strain $M B=2 \cdot 34$; for strain $V C=2 \cdot 03$; for strain $V B=2 \cdot 04$.

\begin{tabular}{|c|c|c|c|c|}
\hline \multirow[b]{2}{*}{ Conen. } & \multicolumn{4}{|c|}{ Organisms } \\
\hline & $\mathbf{M C}$ & MB & VC & VB \\
\hline & \multicolumn{4}{|c|}{ Mean dry weight mycelium (mg./flask) } \\
\hline $\mathbf{P}_{\mathbf{1}}$ & 152 & 143 & 137 & 127 \\
\hline $\mathbf{P}_{\mathbf{2}}$ & 154 & 148 & 147 & 127 \\
\hline $\mathbf{P}_{\mathbf{3}}$ & 143 & 144 & 143 & 129 \\
\hline $\mathbf{M g}_{1}$ & 142 & 143 & 145 & 132 \\
\hline $\mathrm{Mg}_{8}$ & 148 & 143 & 144 & 128 \\
\hline $\mathrm{Mg}_{3}$ & 158 & 143 & 141 & 124 \\
\hline $\mathbf{N}_{1}$ & 132 & 119 & 141 & 126 \\
\hline $\mathbf{N}_{\mathbf{2}}$ & 171 & 163 & 144 & 134 \\
\hline $\mathbf{N}_{3}$ & 145 & 148 & 142 & 124 \\
\hline Mean & $149 \cdot 4$ & 148.2 & $142 \cdot 5$ & $127 \cdot 8$ \\
\hline
\end{tabular}

General mean $=140.7 \mathrm{mg}$. dry wt. mycelium/flask.

In these factorial experiments $\mathrm{KH}_{2} \mathrm{PO}_{4}$ acted as a nutrient because its buffering effect was counteracted by the tris buffer which maintains the acidity at a constant value (Fothergill \& Yeoman, 1956). The experiments indicated that a high degree of balance between the salts of the first order of interaction produced the highest yields of mycelium, but this balance was only absolute between all the salts in the second order of interaction in the case of organism MC and to a less extent of organism MB. Variation of balance in salt concentrations was thus shown between two different species of the same genus, i.e. between $Z$. moelleri and $Z$. vuillemini. In previous experiments of similar factorial design Talley \& Blank (1941) and Fothergill \& Ashcroft (1955) showed that a correct balance between the mineral constituents of the 
medium was essential in order to obtain a high yield of mycelium with two parasitic fungi, Phymatotrichum omnivorum and Venturia inaequalis, respectively. Fothergill \& Raine (1954) showed that while a correct balance between salts was conducive to good growth, it was not of overriding importance with complementary strains of the saprophytic fungus Mucor hiemalis. Fothergill \& Yeoman (1957) found with the saprophyte Rhizopus stolonifer that a balance existed between $\mathrm{K}_{2} \mathrm{HPO}_{4}$ and $\left(\mathrm{NH}_{4}\right)_{2} \mathrm{SO}_{4}$, but not between these and the other salts in the medium.

Table 3. Analysis of variance (grouped) for Zygorhynchus strains $M C, M B, V C$ and $V B$

Required ' $F$ ' and ' $t$ ' values taken from Snedecor's tables (1934). Sums of squares and mean squares are omitted from table.

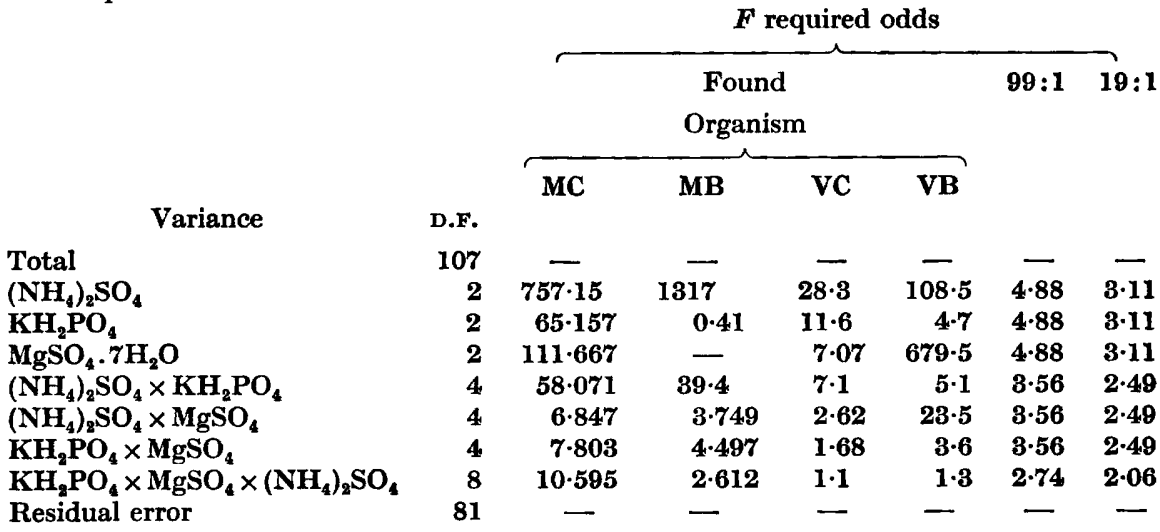

The strains of Zygorhynchus used in the present experiments show several major differences in their nutritional requirements and growth rates. The onset of decrease of dry wt. of mycelium varies with strain from 12 days with the non-sporing forms to 14 days in the sporing forms. Zygorhynchus moelleri and $Z$. vuillemini from the CMI were unable to utilize sucrose as source of carbon, while the strains from Baarn were able to use it to a marked extent. This may indicate the lack of invertase in the British strains. The Baarn strain of $\boldsymbol{Z}$. vuillemini utilized arabinose, but all the strains used sorbose, lactose or raffinose to a small extent, or not at all. Lilly \& Barnett (1953) found that sorbose had an inhibitory effect on the growth of several fungi. The hydrolytic products of lactose and raffinose were utilized by all the strains of Zygorhynchus tested. Thus it seems that these fungi lack the enzymes necessary for the hydrolysis of the higher sugars.

In the experiment on the nitrogen requirement only Zygorhynchus moelleri CMI used $\mathrm{KNO}_{3}$ to any marked extent. The sporing strains of Zygorhynchus gave low mycelial yields with L-glutamine while the non-sporing strains gave high yields. The sporing strains also required higher $\mathrm{Mg}$ concentrations than the non-sporing strains; this may be correlated with Hawker's observation (1950) that magnesium concentration influences sporulation. Hence it may be 
concluded that whilst these four strains of Zygorhynchus have similar basal nutritional requirements there are important differences between them.

The writers thank their colleagues Dr D. A. Evans, and Mr H. Campbell for their assistance with the statistical part of the paper.

\section{REFERENCES}

Burges, A. \& Fenton, E. (1953). The effect of $\mathrm{CO}_{2}$ on the growth of certain soil fungi. Trans. Brit. mycol. Soc. 36, 104.

Fothergill, P. G. \& Ashcroft, R. (1955). The nutritional requirements of Venturia inaequalis. J. gen. Microbiol. 12, 387.

Fothergill, P. G. \& RAINe, L. C. D. P. (1954). The nutritional requirements of Mucor hiemalis. J. gen. Microbiol. 10, 17.

Fothergill, P. G. \& Yeoman, M. M. (1956). Acidity and growth of Rhizopus stolonifer in mineral culture media. Bull. bot. Jard. Brux. 26, 371.

Fothergill, P. G. \& Yeoman, M. M. (1957). The mineral nutrition of Rhizopus stolonifer. J. gen. Microbiol. 17, 631.

Hawker, L. E. (1950). The Physiology of Fungi. Univ. London Press.

Lilly, V. G. \& BARNETT, H. C. (1953). The utilization of sugars by fungi. Bull. $W$. Va. agric. Exp. Sta. 362 T, 5-58.

MACHus, L. (1953). Growth and nutrition of water molds in the subgenus Euallomyces. Amer. J. Bot. 40, 45.

Robins, W. J. (1987). The assimilation by plants of various forms of nitrogen. Amer. J. Bot. 24, 243.

Snedecor, G. W. (1934). Statistical Methods, 4th ed. Iowa State College Press.

Talley, P. J. \& Blank, L. M. (1941). A critical study of the nutritional requirements of Phymatotrichum omnivorum. Plant Physiol. 16, 1.

(Received 14, March 1958) 